\title{
Effect of Sowing Dates and Planting Methods on Quality of Different Order Umbels in Fennel, Fennel Quality as Effected by Different Planting Methods and Time
}

\author{
Hans Raj, V.P.S. Panghal, Makhan Lal, D.S. Duhan, Kuldip Kumar \\ Department of Vegetable Science, CCS Haryana Agricultural University, Hisar, Haryana, India
}

\begin{abstract}
The present experiment was conducted at Vegetable Research Farm, Department of Vegetable Science and Laboratory of Seed Science \& Technology, CCS Haryana Agricultural University, Hisar to study the effect of times and methods of sowing on quality parameters of fennel. The experiment consisted of five dates of sowing (10th, 20th, 30th October, 9th and 19th November) and two planting methods (direct seeding and transplanting). The results showed that seed quality parameters of fennel were influenced significantly by sowing dates. The seed quality parameters like test weight, germination percentage, seedling length and seed vigor index-1 were higher at 10th October sowing/transplanting crop. Regarding planting methods, all the parameters related to quality were found better in direct sown crop than transplanted crop. Test weight of all the main, primary and secondary umbels decreased with delayed sowing and was maximum in case of main umbel seed than primary and secondary umbels. Germination percentage and seed vigor index decreased with delay in sowing from umbels of all categories, irrespective of date of sowing and planting methods. It may be concluded that crop sown on 10th October with direct sown method at Hisar produced bold seed with better seed quality during both the years.
\end{abstract}

Keywords-Fennel, Sowing dates, Planting methods, Quality parameters.

\section{INTRODUCTION}

The fennel (Foeniculum vulgare Miller) is most important seed spices grown on sizeable area throughout the temperate and sub-tropical region of the world for its aromatic seeds which are used as culinary spices. In India, it is mainly cultivated in the state of Gujarat and Rajasthan and to some extent in Uttar Pradesh, Bihar, Madhya Pradesh, Punjab, and Haryana. The importance of seed and its quality cannot be ignored not only because of being basic and cheapest input but it always plays pivotal role in determining the quality as well as quantity production. Seed stored in tropical conditions absorb moisture content, which at high ambient temperature along with high respiration results in deterioration and loss of germ ability. Since the viability of seed, deteriorate rapidly. Therefore, prior assessment of seed quality is important for the coming season. The yield and quality improvement particularly for early season crop, which fetches good market price to the farmers is very much required. Fennel crop can be grown either direct sown or transplanted method in India for good crop (Joshi, 1961). The Time and method of sowing have great importance and significant effect on total yield and quality because these factors ultimately affect the crop duration (Yadav et al., 2000). Therefore, the present study was carried out to study effect of sowing dates and planting methods on seed quality of different order umbels in fennel.

\section{MATERIAL AND METHODS}

The present investigation was conducted at Vegetable Research Farm, Department of Vegetable Science and Laboratotry of Seed Science and Technology department, CCS Haryana Agricultural University, Hisar for two years. The soil of the experimental field was sandy loam, slightly high in $\mathrm{pH}$, low in organic carbon and available nitrogen, medium in available phosphorus and high in available potash. The experiment consisted of five sowing dates (10th, 20th, 30th October, 9th and 19th November) and two planting methods (direct seeding and transplanting) and it was laid out in Randomized Block Design with three replications in a plot measuring $3.0 \mathrm{~m}$ x $2.4 \mathrm{~m}$. Genetically pure seed of fennel variety HF-33 (Hisar- Swarup) were sown in the experimental field, as per sowing date while for transplanting, sowing was done on raised nursery beds of 
$3.0 \times 1.0 \mathrm{~m}$ size on the same date as per treatment. Weeding, thinning and irrigation operations were carried out as and when required. The seedlings were transplanted in the main field 30 days after sowing in the nursery. Experimental data of different parameters were analyzed in three-factor randomized block design with three replications for analysis of variance in OPSTAT (http://14.139.232.166/opstat/index.asp) statistical software developed by Chaudhry Charan Singh Haryana Agricultural University, Hisar, Haryana, India (Sheoran, 2010).

\section{RESULTS AND DISCUSSIONS}

The result of persent investigation showed that seed quality parameters like test weight, germination percentage, seedling length and seed vigour were influenced significantly by sowing dates. Test weight of all the main, primary and secondary umbels decreased with delayed of sowing and was maximum in main umbel seed $(7.72 \mathrm{~g} \&$ $7.82 \mathrm{~g}$ ) than primary and secondary umbels (Table-1) in during both the years 2002-2003 and 20032004 ,respectively. It was because of the fact that umbels on primary and secondary branches appeared at later stages of crop growth and did not get enough time for their growth and development ultimately lesser assimilates were diverted for growth. The secondary and tertiary umbels in late sown crop had forced maturity of seed without proper development resulting in shrinking, hence, the test weight from such seeds was less in case of late sown crop.Similar results were also confirming by Yadav et al. (1996) in fennel crops and Singh and Randhawa (1989) in dill crop . Test weight was not influenced by planting methods (Table1).

Seedling length from seeds obtained from main, primary and secondary umbels followed the similar trend like test weight and maximum seedling legnth was obtained in main umbel on 10th October sowing crop i.e.15.11 cm and $15.95 \mathrm{~cm}$ in 2002-2003and 2003-2004,respectively.Seedling length was decreased with delay sowing period and smallest was found on 19th October sown crop. Probable reason that late sown crop did not get enough growing period and thus plant food assimilates needed for the growth were reduced as period between flower initiation and crop maturity decreased with delay in sowing. Regarding planting methods, no significant difference was found in seedling length of seeds obtained from main, primary and secondary umbels. Howevere it was noticed better in direct sown crop than tranplanted in all categories of umbel in both the year (Table-1).

Germination percentage and seed vigour index decreased with delay in sowing from umbels of all categories. Sowing on 10th October recorded maximum seed germination (94.7 and 95.0\% during 2002-2003 and 2003-2004) in the seeds obtained from main umbel which was statistically at par with 20th and 30th October sowing and these three dates were significantly superior to the remaining two dates. Minimum seed germination was observed on last date of sowing (19th November) in the seeds obtained from all the three order umbels during both the years (Table-2). Germination percentage and seed vigour index was found minimum in secondary order umbel followed by primary umbels. It is because seeds with later planting dates did not have enough stored food and some of the seeds were not fully developed to germinate. Howeever,effect of planting method on seed germination was found non-significant during both the years. Direct sown crop produced bold seed with maximum seed germination percentage and higher vigour index during both the years. This might be due to better growth of plant and normal development of seed. Maximum vigour index of the seeds of all the three order umbels were obtained with first sowing date (10th October) and significantly higher than all other dates except 20th Octoberduring both the year. Lowest vigour index was recorded when sowing was done on 19th November during both the years (Table-2).

\section{CONLUSION}

It may be concluded that crop sown on 10th October with direct sown method in Hisar district produced bold seed with maximum seed germination percentage, test weight, seedling length and higher vigor index during both the years.

\section{REFERENCES}

[1] Joshi, A.B. (1961). These new spices will pay you well. Indian Fmg. 10(10): 26-28.

[2] Sheoran, O. P. (2010). Online Statistical Analysis (OPSTAT). Software developed by Chaudhary Charan Singh Haryana Agricultural University, Hisar, Haryana, India http://www.hau.ernet.in/opstat.html.

[3] Singh, A. and Randhawa, G.S. (1989). Plant population and seed yield of dill as influenced by some agronomic factors. Haryana J. Agron. 5(2): 110-114.

[4] Yadav, A.C., Batra, B.R., Yadav, S.K. and Malik, Y.S. (1996). Effect of irrigation and date of sowing on seed yield and quality of fennel (Foeniculum vulgare Mill.). Proc. Silver Jubilee Nat. Symp. Arid Hort. HAU, Hisar, Dec. 5-6, 1996. pp. 343-345.

[5] Yadav, B.D., Khurana, S.C., Thakral, K.K. and Malik, Y.S. (2000). Effect of sowing dates and planting methods on quality of seed produced by different order umbels in fennel. Haryana J. hort. Sci. 29(1-2): 108-110. 
Table.1: Effect of time and method of sowing on test weight $(\mathrm{g})$ and seedling length $(\mathrm{cm})$ in different order umbels in fennel

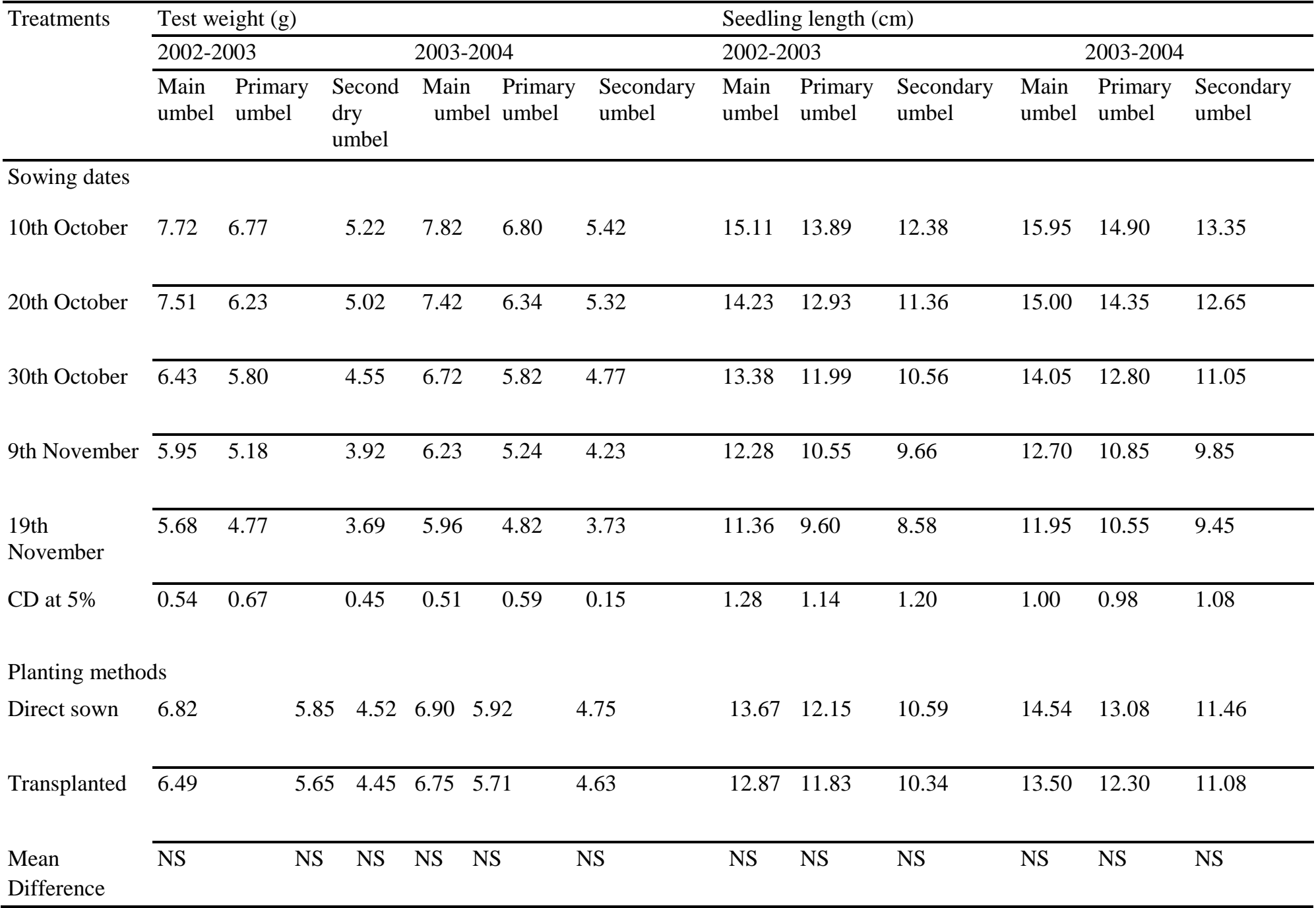


Table.2: Effect of time and method of sowing on seed germination percentage and Seed vigour index-1 of different order umbels in fennel

\begin{tabular}{|c|c|c|c|c|c|c|c|c|c|c|c|c|}
\hline \multirow[t]{3}{*}{ Treatments } & \multicolumn{6}{|c|}{ Seed germination percentage } & \multicolumn{6}{|c|}{ Seed vigour index-1 } \\
\hline & \multicolumn{3}{|c|}{$2002-2003$} & \multicolumn{3}{|c|}{$2003-2004$} & \multicolumn{3}{|c|}{$2002-2003$} & \multicolumn{3}{|c|}{$2003-2004$} \\
\hline & $\begin{array}{l}\text { Main } \\
\text { umbel }\end{array}$ & $\begin{array}{l}\text { Prima } \\
\text { ry } \\
\text { umbel }\end{array}$ & $\begin{array}{l}\text { Secon } \\
\text { dry } \\
\text { umbel }\end{array}$ & $\begin{array}{l}\text { Main } \\
\text { umbel }\end{array}$ & $\begin{array}{l}\text { Prim } \\
\text { ary } \\
\text { umbel }\end{array}$ & $\begin{array}{l}\text { Secondary } \\
\text { umbel }\end{array}$ & $\begin{array}{l}\text { Main } \\
\text { umbel }\end{array}$ & $\begin{array}{l}\text { Primary } \\
\text { umbel }\end{array}$ & $\begin{array}{l}\text { Secondary } \\
\text { umbel }\end{array}$ & $\begin{array}{l}\text { Main } \\
\text { umbel }\end{array}$ & $\begin{array}{l}\text { Primary } \\
\text { umbel }\end{array}$ & $\begin{array}{l}\text { Secondary } \\
\text { umbel }\end{array}$ \\
\hline \multicolumn{13}{|l|}{ Sowing date } \\
\hline 10th October & 94.7 & 93.7 & 87.4 & 95.0 & 93.9 & 88.6 & 1435.6 & 1305.4 & 1085.0 & 1519.2 & 1407.8 & 1183.3 \\
\hline 20th October & 94.1 & 92.8 & 86.3 & 94.2 & 92.6 & 88.0 & 1344.0 & 1205.9 & 983.3 & 1417.0 & 1340.9 & 1100.6 \\
\hline 30th October & 93.9 & 92.0 & 85.0 & 93.9 & 91.8 & 85.9 & 1260.8 & 1120.8 & 901.6 & 1377.3 & 1165.8 & 954.8 \\
\hline $\begin{array}{l}\text { 9th } \\
\text { November }\end{array}$ & 89.1 & 88.2 & 79.6 & 89.2 & 87.3 & 79.9 & 1097.1 & 934.6 & 773.2 & 1136.0 & 949.2 & 789.6 \\
\hline $\begin{array}{l}19 \text { th } \\
\text { November }\end{array}$ & 88.0 & 84.2 & 77.0 & 85.9 & 83.0 & 77.4 & 1004.4 & 811.6 & 665.8 & 1028.9 & 895.0 & 733.4 \\
\hline $\mathrm{CD}$ at $5 \%$ & 1.9 & 2.1 & 2.5 & 1.5 & 2.6 & 2.8 & 118.1 & 107.4 & 104.3 & 110.9 & 97.7 & 85.6 \\
\hline \multicolumn{13}{|c|}{ Planting methods } \\
\hline Direct sown & 92.5 & 90.6 & 84.2 & 92.2 & 91.0 & 85.0 & 1273.0 & 1110.7 & 915.6 & 1350.8 & 1200.0 & 982.8 \\
\hline Transplanted & 91.3 & 89.7 & 82.0 & 91.0 & 88.4 & 82.6 & 1183.1 & 1040.1 & 847.8 & 1240.4 & 1103.4 & 921.8 \\
\hline $\begin{array}{l}\text { Mean } \\
\text { Difference }\end{array}$ & $\mathrm{NS}$ & NS & NS & NS & NS & NS & 74.7 & 68.1 & 66.0 & 70.2 & 61.7 & 54.2 \\
\hline
\end{tabular}

